\title{
Aplikasi Pupuk Organik Cair dan N, P, K Terhadap C-Organik, N-Total, Serapan N Serta Hasil Padi Sawah (Oryza sativa L.) Pada Inceptisol Asal Jatinangor
}

\author{
Rija Sudirjaํㅜ ${ }^{1}$ Maya Damayani ${ }^{1}$, Eso Solihin ${ }^{1}$, Wulan Sri Damayanti² ${ }^{2}$ Apong Sandrawati \\ 1)Departemen Ilmu Tanah dan Sumberdaya Lahan, Fakultas Pertanian Universitas Padjadjaran \\ 2) Program Studi Agroteknologi Fakultas Pertanian Universitas Padjadjaran \\ Jl. Raya Bandung Sumedang Km 21 Jatinangor, Sumedang
}

Korespondensi: rija.sudirja@unpad.ac.id

\begin{abstract}
Rice is one of the staples of Indonesian society. Development of rice cultivation can be carried out on Inceptisol soils. This land has a wide distribution of around 70.52 million, but it has an unfavorable fertility rate so fertilization is needed in order to increase fertility and yield of lowland rice. This study aims to determine the effect of a combination of liquid organic fertilizer and $N, P, K$ fertilizer on $C$ Organic, $N$-Total, $N$ uptake and Yield (Oryza Sativa L.) on Inceptisol from Jatinangor. The experiment was held on March 2019 until July 2019 at Ciparanje Experimental Field and Laboratory Soil Chemistry and Plant Nutrition, Faculty of Agriculture, Padjadjran University, Jatinangor, Sumedang. The experimental design was Randomized Block Design with ten treatments and three replications. The result of study showed that the combination of liquid organic fertilizer and $N, P, K$ is affected on organic $C$, total $N, N$ uptake and rice yield. The application of one liquid organik fertilizer and $3 / 4 N, P$, $K$ gave the best rice yield of $8,55 \mathrm{~kg} / \mathrm{plot}$ or equal to $6,84 \mathrm{ton} / \mathrm{ha}$.
\end{abstract}

Keywords: Inceptisol, Liquid Organic Fertilizer, N uptake, Organic C, Rice Yield, Total N.

\section{PENDAHULUAN}

Padi (Oryza sativa L.) merupakan tanaman penghasil beras yang menjadi bahan pangan pokok bagi sebagian besar masyarakat Indonesia. Berdasarkan data Badan Pusat Statistik (2018), Tingkat konsumsi beras di Indonesia pada tahun 2017 rata-rata 111,58 $\mathrm{kg} / \mathrm{kapita/tahun.} \mathrm{Sementara} \mathrm{itu,} \mathrm{jumlah}$ penduduk semakin bertambah, terhitung 258,48 juta jiwa di tahun 2016 meningkat menjadi 265 juta jiwa pada tahun 2017. Maka konsumsi beras nasional pun diprediksi akan semakin bertambah seiring dengan pertambahan penduduk. Oleh sebab itu, tingginya permintaan beras harus diimbangi dengan produksi dan ketersediaannya.

Produksi komoditas pertanian dipengaruhi oleh faktor alam, tenaga dan modal (Suratiyah, 2006). Faktor alam yang sangat penting bagi produksi tanaman adalah tanah. Inceptisol sebagai lahan pertanian dapat digunakan sebagai lahan kering dan lahan basah atau sawah. Inceptisol merupakan salah satu ordo tanah yang terdapat di wilayah Indonesia dengan luas 70,52 juta ha. Penyebaran Inceptisol di Indonesia cukup luas, salah satunya terdapat di Jawa Barat yaitu sekitar 2,119 juta ha (Pusat Penelitian Tanah dan Agroklimat, 2000). Salah satu penyebaran tanah sawah Inceptisol tersebar di Jawa Barat yaitu di Kecamatan Jatinangor, Kabupaten Sumedang. Pada umumnya Inceptisol memliki tingkat kesuburan rendah hingga sedang. Selain itu, menurut Nursyamsi, dkk (2002) tanah Inceptisol juga memiliki kandungan bahan organik rendah hingga sedang.

Salah satu upaya untuk meningkatkan kesuburan tanah adalah dengan pemupukan. Berdasarkan bahannya, pupuk dapat dibedakan menjadi dua jenis yaitu pupuk organik dan pupuk anorganik. Penggunaan pupuk organik dikombinasikan dengan pupuk anorganik merupakan strategi untuk meningkatkan produktivitas tanah, hasil tanaman dan mengurangi dosis penggunaan pupuk anorganik (Sulaeman dkk., 2017). 
Hasil penelitian Suwartil dan Sukritiyunobowo (2009) juga menunjukan bahwa pupuk organik cair MM-17 yang dikombinasikan dengan pupuk anorganik NPK berpengaruh terhadap sifat kimia tanah, yaitu meningkatkan kadar C-organik, N-total, P-total dan P-tersedia. Kombinasi ini juga berpengaruh terhadap peningkatan hasil gabah kering bersih tanaman padi. Supramudho dkk. (2012) mengemukakan bahwa peningkatan berat gabah tanaman padi berkaitan erat dengan serapan hara $\mathrm{N}$ yang meningkat.

Penelitian ini bertujuan untuk mgengetahui pengaruh pemberian pupuk cair organik dan $\mathrm{N}, \mathrm{P}, \mathrm{K}$ dengan berbagai dosis perlakuan dan pengaruhnya tehadap kadar Corganik, N-total, serapan $\mathrm{N}$, dan hasil gabah pada sawah di Inceptisol asal Jatinangor.

\section{METODOLOGI}

Percobaan ini dilaksanakan di lahan sawah Kebun Percobaan Ciparanje Fakultas Pertanian Universitas Padjadjaran, Jatinangor, Sumedang, yang terletak pada ketinggian 723 $\mathrm{m}$ dpl. Percobaan berlangsung dari bulan Maret sampai dengan Juli 2019.

Alat yang digunakan dalam percobaan ini meliputi peralatan lapangan seperti cangkul dan caplak, serta peralatan di laboratorium yaitu neraca analitik, labu ukur, labu Kjeldahl, erlenmeyer, alat destilasi, buret, hot plate/ Kjeldahltherm, tabung disgestion dan blok disgestion.

Bahan yang digunakan dalam percobaan ini diantaranya: benih padi sawah varietas Ciherang, pupuk organik cair, pupuk Urea, SP36, dan $\mathrm{KCl}$, pestisida, dan bahan kimia yang digunakan pada analisis tanah dan tanaman di laboratorium.

Percobaan ini didesain dengan menggunakan metode Rancangan Acak Kelompok (RAK) dengan 10 perlakuan. Masing-masing perlakuan diulang tiga kali sehingga total perlakuan seluruhnya adalah $10 \times 3=30$ plot percobaan. Ukuran plot percobaan yang diggunakan adalah $2 \times 5 \mathrm{~m}$.

Tabel 1 Macam Perlakuan Pemupukan

\begin{tabular}{ccccc}
\hline \multirow{3}{*}{ Perlakuan } & \multicolumn{4}{c}{ Dosis pupuk / ha } \\
\cline { 2 - 5 } & $\begin{array}{c}\text { POC } \\
(\mathrm{L})\end{array}$ & $\begin{array}{c}\text { Urea } \\
(\mathrm{kg})\end{array}$ & $\begin{array}{c}\text { SP-36 } \\
(\mathrm{kg})\end{array}$ & $\begin{array}{c}\mathrm{KCl} \\
(\mathrm{kg})\end{array}$ \\
\hline $\mathrm{A}$ & 0 & 0 & 0 & 0 \\
$\mathrm{~B}^{*}$ & 0 & 300 & 50 & 50 \\
$\mathrm{C}$ & 4 & 0 & 0 & 0 \\
D & 4 & 75 & 12,5 & 12,5 \\
E & 4 & 150 & 25 & 25 \\
F & 4 & 225 & 37,5 & 37,5 \\
G & 4 & 300 & 50 & 50 \\
H & 1 & 225 & 37,5 & 37,5 \\
I & 2 & 225 & 37,5 & 37,5 \\
J & 3 & 225 & 37,5 & 37,5 \\
\hline
\end{tabular}

* : Dosis anjuran pupuk N, P, K berdasarkan Permentan No.40 tahun 2007

Parameter sifat tanah yang diuji meliputi kadar C-organik yang ditetapkan dengan metode Walkley and Black, kadar N-total tanah yang ditetapkan dengan metode Kjeldahl, serapan $\mathrm{N}$ tanaman yang didestruksi dengan pengabuan basah dan ditetapkan dengan metode Kjeldahl. Selain itu, parameter lain yang diukur adalah bobot gabah kering panen (GKP), yang diukur per rumput tanaman.

Pengolahan lahan dilakukan dengan cara pembajakan dan pelumpuran tanah hingga rata. Kemudian dilakukan penggarisan untuk menentukan letak penanaman bibit dengan jarak tanam $25 \times 25 \mathrm{~cm}$. Penanaman dilakukan pada saat bibit berumur 14 hari setelah semai. Bibit yang akan digunakan memiliki tinggi seragam, daun tidak kuning, dan tidak terdapat gejala serangan penyakit.

Pemberian pupuk organik cair dilakukan setiap dua minggu sekali selama masa vegetatif dengan cara disemprotkan ke seluruh bagian tanaman dengan merata. Sedangkan pemberian pupuk Urea dilakukan sebanyak tiga kali yakni pada saat tanaman berumur 7 , 
21, dan 42 HST. Pemberian pupuk SP-36 dan $\mathrm{KCl}$ dilakukan pada saat tanaman berumur 7 HST, kedua pupuk tersebut diaplikasikan dengan disebar merata di atas permukaan tanah. Pemeliharaan tanaman padi meliputi pengairan, penyulaman dan pengendalian OPT.

Pengambilan contoh tanah dan tanaman yang akan dianalisis diambil pada saat masa vegetatif maksimum saat tanaman berumur 58 HST. Titik pengambilan contoh tanah dan tanaman ditetapkan secara acak pada masingmasing petak. Kegiatan pemanenan padi dilakukan pada 124 HST. Padi yang siap panen memiliki ciri-ciri seperti: daun tanaman telah menguning dan bulir padi menguning sekitar $95 \%$. Pemanenan dilakukan dengan memotong bagian pangkal malai padi kemudian bulir padi dirontokkan dari malainya secara manual. Hasil bulir ditimbang untuk memperoleh bobot Gabah Kering Panen (GKP) tiap perlakukan percobaan.

\section{HASIL DAN PEMBAHASAN}

\subsection{Pengaruh Macam Perlakuan terhadap C-Organik Tanah}

Nilai C-organik pada semua perlakuan berkisar antara 2,19 - 2,55 \% (Tabel 2).

Tabel 2 Hasil pengukuran dan analisis ragam masing-masing perlakuan terhadap kadar C-organik

\begin{tabular}{lc}
\hline \multicolumn{1}{c}{ Perlakuan } & $\begin{array}{c}\text { C-Organik } \\
(\%)\end{array}$ \\
\hline $\mathrm{A}=$ Kontrol $(0 \mathrm{POC}+0 \mathrm{~N}, \mathrm{P}, \mathrm{K})$ & $2,19 \mathrm{a}$ \\
$\mathrm{B}=0$ POC $+\mathrm{N}, \mathrm{P}, \mathrm{K}$ Standar $(1 \mathrm{~N}, \mathrm{P}, \mathrm{K})$ & $2,12 \mathrm{a}$ \\
$\mathrm{C}=1 \mathrm{POC}+0 \mathrm{~N}, \mathrm{P}, \mathrm{K}$ & $2,55 \mathrm{~b}$ \\
$\mathrm{D}=1 \mathrm{POC}+1 / 4 \mathrm{~N}, \mathrm{P}, \mathrm{K}$ & $2,53 \mathrm{~b}$ \\
$\mathrm{E}=1$ POC $+1 / 2 \mathrm{~N}, \mathrm{P}, \mathrm{K}$ & $2,55 \mathrm{~b}$ \\
$\mathrm{~F}=1 \mathrm{POC}+3 / 4 \mathrm{~N}, \mathrm{P}, \mathrm{K}$ & $2,56 \mathrm{~b}$ \\
$\mathrm{G}=1$ POC $+1 \mathrm{~N}, \mathrm{P}, \mathrm{K}$ & $2,57 \mathrm{~b}$ \\
$\mathrm{H}=1 / 4 \mathrm{POC}+3 / 4 \mathrm{~N}, \mathrm{P}, \mathrm{K}$ & $2,50 \mathrm{~b}$ \\
$\mathrm{I}=1 / 2 \mathrm{POC}+3 / 4 \mathrm{~N}, \mathrm{P}, \mathrm{K}$ & $2,52 \mathrm{~b}$ \\
$\mathrm{~J}=3 / 4 \mathrm{POC}+3 / 4 \mathrm{~N}, \mathrm{P}, \mathrm{K}$ & $2,53 \mathrm{~b}$ \\
\hline Keterangan $\quad$ Nilai yang diikuti oleh huruf yang sama \\
tidak berbeda nyata berdasarkan Uji \\
Lanjut Duncan pada taraf nyata $5 \%$.
\end{tabular}

Berdasarkan hasil analisis ragam, aplikasi POC (perlakuan C, D, E, F, G, H, I, dan J) berbeda nyata dengan kontrol (A) dan perlakuan pupuk standar (B). Pemberian POC akan meningkatkan kadar C-organik tanah. Hal ini sejalan dengan hasil penelitian Febrianna dkk. (2018) dimana setiap pemberian POC pada tanah akan meningkatkan kandungan bahan organik di dalam tanah. Hal ini dikarenakan POC juga merupakan jenis bahan organik, penambahan bahan organik akan berbanding lurus dengan peningkatan kadar C-organik (Wahyudi, 2009).

\subsection{Pengaruh Perlakuan Pemupukan terhadap N-Total Tanah}

Hasil pengukuran dan analisis ragam terhadap kadar $\mathrm{N}$-total menunjukkan bahwa macam perlakuan pemupukan POC dan N, P, K mempengaruhi nilai $\mathrm{N}$-total hasil yang berbeda nyata terhadap $\mathrm{N}$-total pada Inceptisol asal Jatinangor (Tabel 3).

Tabel 3 Pengaruh Pupuk Organik Cair dan Pupuk N, P, K terhadap N-Total Inceptisol Asal Jatinangor

\begin{tabular}{lc}
\hline \multicolumn{1}{c}{ Perlakuan } & $\begin{array}{c}\text { N-Total } \\
(\%)\end{array}$ \\
\hline $\mathrm{A}=$ Kontrol $(0 \mathrm{POC}+0 \mathrm{~N}, \mathrm{P}, \mathrm{K})$ & $0,22 \mathrm{a}$ \\
$\mathrm{B}=0 \mathrm{POC}+\mathrm{N}, \mathrm{P}, \mathrm{K}$ Standar $(1 \mathrm{~N}, \mathrm{P}, \mathrm{K})$ & $0,30 \mathrm{bc}$ \\
$\mathrm{C}=1 \mathrm{POC}+0 \mathrm{~N}, \mathrm{P}, \mathrm{K}$ & $0,26 \mathrm{ab}$ \\
$\mathrm{D}=1 \mathrm{POC}+1 / 4 \mathrm{~N}, \mathrm{P}, \mathrm{K}$ & $0,27 \mathrm{bc}$ \\
$\mathrm{E}=1 \mathrm{POC}+1 / 2 \mathrm{~N}, \mathrm{P}, \mathrm{K}$ & $0,27 \mathrm{bc}$ \\
$\mathrm{F}=1 \mathrm{POC}+3 / 4 \mathrm{~N}, \mathrm{P}, \mathrm{K}$ & $0,31 \mathrm{c}$ \\
$\mathrm{G}=1 \mathrm{POC}+1 \mathrm{~N}, \mathrm{P}, \mathrm{K}$ & $0,31 \mathrm{c}$ \\
$\mathrm{H}=1 / 4 \mathrm{POC}+3 / 4 \mathrm{~N}, \mathrm{P}, \mathrm{K}$ & $0,28 \mathrm{bc}$ \\
$\mathrm{I}=1 / 2 \mathrm{POC}+3 / 4 \mathrm{~N}, \mathrm{P}, \mathrm{K}$ & $0,28 \mathrm{bc}$ \\
$\mathrm{J}=3 / 4 \mathrm{POC}+3 / 4 \mathrm{~N}, \mathrm{P}, \mathrm{K}$ & $0,28 \mathrm{bc}$ \\
\hline Keterangan $:$ Nilai yang diikuti oleh huruf yang sama \\
\multicolumn{2}{c}{ tidak berbeda nyata berdasarkan Uji } \\
Lanjut Duncan pada taraf nyata $5 \%$.
\end{tabular}

Tabel 3 menunjukkan bahwa perlakuan B (N, P, K Standar) hingga perlakuan J (3/4 POC + $3 / 4 \mathrm{~N}, \mathrm{P}, \mathrm{K}$ ) dengan pemberian $\mathrm{POC}$, pupuk N, $\mathrm{P}$, $\mathrm{K}$ dan kombinasinya berpengaruh terhadap $\mathrm{N}$ total tanah dibandingkan dengan perlakuan $\mathrm{A}$ (Kontrol/tanpa pemberian pupuk). Perlakuan $\mathrm{F}(1 \mathrm{POC}+3 / 4 \mathrm{~N}, \mathrm{P}, \mathrm{K})$ dan G $(1 \mathrm{POC}+1 \mathrm{~N}, \mathrm{P}, \mathrm{K})$ 
memberikan pengaruh paling baik jika dibandingkan dengan perlakuan lainnya yakni terjadi peningkatan $\mathrm{N}$-total tanah dari $0,22 \%$ (tanah awal) menjadi 0,31\%.

Pemberian POC dan N, P, K cenderung memberikan peningkatan $\mathrm{N}$-total tanah dibandingkan dengan tanpa pemupukan. Hal ini diduga karena penambahan unsur $\mathrm{N}$ (3,10\%) dan C-Organik (7,2\%) dari POC dapat meningkatkan $\mathrm{N}$-total tanah. Berdasarkan hasil penelitian Firmansyah dan Sumarni (2013) pemberian pupuk $\mathrm{N}$ khususnya dari pupuk Urea dapat menyebabkan $\mathrm{N}$-total yang tersedia di dalam tanah meningkat.

\subsection{Pengaruh Perlakuan Terhadap Serapan N Tanaman Padi}

Hasil pengukran dan analisis ragam (Tabel 4) menunjukkan bahwa kombinasi dosis Pupuk Organik Cair (POC) dan N, P, K berbeda nyata terhadap serapan $\mathrm{N}$ tanaman (Tabel 4).

Tabel 4 Hasil pengukurann dan Analisis Ragam terhadap Serapan N Tanaman Padi

\begin{tabular}{lc}
\hline \multicolumn{1}{c}{ Perlakuan } & $\begin{array}{c}\text { Serapan N } \\
(\mathrm{mg} / \text { tanaman })\end{array}$ \\
\hline $\mathrm{A}=$ Kontrol & $174,79 \mathrm{a}$ \\
$\mathrm{B}=\mathrm{N}, \mathrm{P}, \mathrm{K}$ Standar & $301,31 \mathrm{~d}$ \\
$\mathrm{C}=1 \mathrm{POC}+0 \mathrm{~N}, \mathrm{P}, \mathrm{K}$ & $182,94 \mathrm{ab}$ \\
$\mathrm{D}=1 \mathrm{POC}+1 / 4 \mathrm{~N}, \mathrm{P}, \mathrm{K}$ & $185,43 \mathrm{ab}$ \\
$\mathrm{E}=1 \mathrm{POC}+1 / 2 \mathrm{~N}, \mathrm{P}, \mathrm{K}$ & $211,51 \mathrm{ab}$ \\
$\mathrm{F}=1 \mathrm{POC}+3 / 4 \mathrm{~N}, \mathrm{P}, \mathrm{K}$ & $353,98 \mathrm{e}$ \\
$\mathrm{G}=1 \mathrm{POC}+1 \mathrm{~N}, \mathrm{P}, \mathrm{K}$ & $314,60 \mathrm{de}$ \\
$\mathrm{H}=1 / 4 \mathrm{POC}+3 / 4 \mathrm{~N}, \mathrm{P}, \mathrm{K}$ & $229,29 \mathrm{bc}$ \\
$\mathrm{I}=1 / 2$ POC $+3 / 4 \mathrm{~N}, \mathrm{P}, \mathrm{K}$ & $271,86 \mathrm{~cd}$ \\
$\mathrm{~J}=3 / 4 \mathrm{POC}+3 / 4 \mathrm{~N}, \mathrm{P}, \mathrm{K}$ & $267,30 \mathrm{~cd}$ \\
\hline Keterangan $:$ Nilai yang diikuti oleh huruf yang sama \\
tidak berbeda nyata berdasarkan Uji \\
\multicolumn{2}{c}{ Lanjut Duncan pada taraf nyata $5 \%}$.
\end{tabular}

Tabel 4 menunjukkan bahwa perlakuan B (N, P, K Standar) hingga perlakuan J ( $3 / 4$ POC + $3 / 4 \mathrm{~N}, \mathrm{P}, \mathrm{K}$ ) dengan pemberian POC, pupuk N, $\mathrm{P}$, $\mathrm{K}$ dan kombinasinya memberikan pengaruh baik dalam meningkatkan serapan $\mathrm{N}$ tanaman dibandingkan dengan perlakuan A (Kontrol/ tanpa pemberian pupuk). Perlakuan F (1 POC + $3 / 4 \mathrm{~N}, \mathrm{P}, \mathrm{K})$ memberikan pengaruh paling baik jika dibandingkan dengan perlakuan lainnya, yaitu sebesar 353,98 mg/tanaman atau setara $45,31 \mathrm{~kg} / \mathrm{ha}$. Hal ini sejalan dengan hasil penelitian Purnomo (2008), dimana pemberian berbagai dosis pupuk $\mathrm{N}$ pada tanaman padi dapat meningkatkan serapan $\mathrm{N}$ tanaman padi $45-59 \mathrm{~kg} / \mathrm{ha}$ pada saat tanaman padi berumur 6 MST. Pada penelitian ini, pemberian POC dan NPK secara signifikan mempengaruhi peningkatan serapan $\mathrm{N}$ tanaman.

\subsection{Pengaruh Perlaukan Terhadap Gabah Kering Panen}

Hasil analisis ragam menunjukkan bahwa pemberian POC dan N, P, K memberikan hasil yang berbeda nyata terhadap Gabah Kering Panen (Tabel 5). Pemberian POC, pupuk N, P, K dan kombinasinya mempengaruhi peningkatan hasil GKP dibandingkan dengan tanpa pemberian pupuk.

Tabel 5 Hasil Pengukuran dan Analisis Ragam terhadap Gabah Kering Panen (GKP)

\begin{tabular}{lc}
\hline \multicolumn{1}{c}{ Perlakuan } & $\begin{array}{c}\text { GKP } \\
(\mathrm{kg} / \text { petak })\end{array}$ \\
\hline $\mathrm{A}=$ Kontrol & $4,12 \mathrm{a}$ \\
$\mathrm{B}=\mathrm{N}, \mathrm{P}, \mathrm{K}$ Standar & $7,22 \mathrm{ef}$ \\
$\mathrm{C}=1 \mathrm{POC}+0 \mathrm{~N}, \mathrm{P}, \mathrm{K}$ & $4,45 \mathrm{a}$ \\
$\mathrm{D}=1 \mathrm{POC}+1 / 4 \mathrm{~N}, \mathrm{P}, \mathrm{K}$ & $4,99 \mathrm{~b}$ \\
$\mathrm{E}=1 \mathrm{POC}+1 / 2 \mathrm{~N}, \mathrm{P}, \mathrm{K}$ & $5,78 \mathrm{c}$ \\
$\mathrm{F}=1 \mathrm{POC}+3 / 4 \mathrm{~N}, \mathrm{P}, \mathrm{K}$ & $8,55 \mathrm{~g}$ \\
$\mathrm{G}=1 \mathrm{POC}+1 \mathrm{~N}, \mathrm{P}, \mathrm{K}$ & $8,72 \mathrm{~g}$ \\
$\mathrm{H}=1 / 4 \mathrm{POC}+3 / 4 \mathrm{~N}, \mathrm{P}, \mathrm{K}$ & $6,75 \mathrm{~d}$ \\
$\mathrm{I}=1 / 2 \mathrm{POC}+3 / 4 \mathrm{~N}, \mathrm{P}, \mathrm{K}$ & $6,93 \mathrm{de}$ \\
$\mathrm{J}=3 / 4 \mathrm{POC}+3 / 4 \mathrm{~N}, \mathrm{P}, \mathrm{K}$ & $7,84 \mathrm{e}$ \\
\hline Keterangan $:$ Nilai yang diikuti oleh huruf yang sama \\
\multicolumn{2}{c}{ tidak berbeda nyata berdasarkan Uji } \\
\multicolumn{2}{c}{ Lanjut Duncan pada taraf nyata $5 \%}$.
\end{tabular}

Perlakuan F $(1$ POC $+3 / 4$ N, P, K $)$ dan perlakuan G (1 POC $+1 \mathrm{~N}, \mathrm{P}, \mathrm{K})$ memberikan pengaruh nyata pada hasil GKP dibandingkan dengan perlakuan lainnya dengan hasil GKP sebesar 8,55 dan 8,72 kg/petak. Perlakuan F (1 $\mathrm{POC}+3 / 4 \mathrm{~N}, \mathrm{P}, \mathrm{K})$ merupakan kombinasi terbaik, 
karena dengan pengurangan penggunaan pupuk anorganik N, P, K ( $3 / 4$ dari dosis anjuran) dapat meningkatan hasil GKP yang hampir setara dengan hasil GKP dengan pupuk N, P, K pada perlakuan $\mathrm{G}(1 \mathrm{POC}+1 \mathrm{~N}, \mathrm{P}, \mathrm{K})$.

Hasil produksi gabah pada tanaman padi dipengaruhi oleh pertumbuhan tanaman seperti jumlah anakan produktif. Unsur hara yang berperan penting fase vegetatif adalah Nitrogen. Menurut Patti dkk. (2013) nitrogen dapat mempengaruhi pertumbuhan tanaman pada parameter jumlah anakan, luas permukaan daun, pembentukan dan pengisian gabah, serta sintesis protein. Soplanit dan Nukuhaly (2012) menambahkan bahwa ketersediaan $\mathrm{N}$ yang cukup pada fase generatif dapat memperlambat proses penuaan daun, sehingga apat berjalan dengan baik. Hasil fotosintat akan berpengaruh kepada proses pengisian gabah dan peningkatan protein dalam gabah.

\section{KESIMPULAN}

Berdasarkan hasil percobaan, dapat disimpulkan bahwa pemberian pupuk organik cair dan N, P, K memberikan pengaruh dalam meningkatkan C-organik, N-total, serapan $\mathrm{N}$ serta hasil padi sawah (Oryza sativa L.) pada Inceptisol asal Jatinangor. Selain itu, pemberian pupuk organik cair dapat mengurangi penggunaan pupuk anorganik $\mathrm{N}$, $\mathrm{P}, \mathrm{K}$ dalam meningkatkan produksi tanaman padi. Pemberian dosis 1 POC dan 3/4 N, P, K memberikan pengaruh lebih baik dibandingkan perlakuan lainnya terhadap hasil padi sawah (Oryza sativa L.) pada Inceptisol asal Jatinangor, yaitu sebesar $8,55 \mathrm{~kg} /$ petak atau setara dengan 6,84 ton/hektar.

\section{DAFTARPUSTAKA}

Badan Pusat Statistik. 2018. Ringkasan Eksekutip Luas Panen dan Produksi Beras di Indonesia 2018 dalam https://www.bps.go.id. Diakses pada tanggal 25 Juni 2019.

Febrianna, M., S. Prijono dan N. Kusumarini. 2018. Pemanfaatan pupuk organik cair untuk meningkatkan serapan nitrogen serta pertumbuhan dan produksi sawi (Brassica Juncea L.) pada tanah berpasir. Jurnal Tanah dan Sumberdaya Lahan 5(2): 1009 - 1018.

Firmansyah, I dan Sumarni, N. 2013. Pengaruh dosis pupuk $\mathrm{N}$ dan varietas terhadap $\mathrm{pH}$ tanah, $\mathrm{N}$-total tanah, serapan $\mathrm{N}$ dan hasil umbi bawang merah (Allium ascalonicum L.) pada tanah EntisolsBrebes Jawa Tengah. Jurnal Hortikultura, 23(4):358-364.

Nursyamsi, D., Budiarto dan L. Anggria. 2002. Pengelolaan Kahat Hara pada Inceptisols untuk Meningkatkan Pertumbuhan Tanaman Jagung. Jurnal Tanah Dan Iklim, 20/2002; 56-68

Patti P. S., E. Kaya dan Ch. Silahooy. 2013. Analisis status nitrogen tanah dalam kaitannya dengan serapan $\mathrm{N}$ oleh tanaman padi sawah di Desa Waimital, Kecamatan Kairatu, Kabupaten Seram Bagian Barat. Agrologia, 2(1): 51-58.

Purnomo, J. 2008. Pengaruh pupuk NPK majemuk terhadap hasil padi varietas Ciherang dan sifat kimia tanah Inceptisol, Bogor. Dalam Anda, M (eds). Prosiding Seminar Nasional dan Dialog Sumberdaya Lahan Pertanian. Balittanah. Bogor, 18 - 20 Novemver 2008.

Pusat Penelitian Tanah dan Agroklimat. 2000. Sumber Daya Lahan Indonesia dan Pengelolaannya. Badan Penelitian dan Pengembangan Pertanian (BPPP), Bogor.

Soplanit, R. dan S.H. Nukuhaly. 2012. Pengaruh pengelolaan hara NPK terhadap ketersediaan $\mathrm{N}$ dan hasil tanaman padi sawah (Oryza sativa L.) di Desa Waelo 
Kecamatan Waeapo Kabupaten Buru. Agrologia, 1(1): 81-90.

Sulaeman, Y., Maswar dan D. Erfandi. 2017. Pengaruh kombinasi pupuk organik dan anorganik terhadap sifat kimia tanah, dan hasil tanaman jagung di lahan kering masam. Jurnal Pengkajian dan Pengembangan Teknologi Pertanian, 20(1): 1 - 12.

Supramudho, G. N., J. Syamsiyah, Mujiyo dan Sumani. 2012. Efisiensi serapan Nitrogen dan hasil tanaman padi pada berbagai imbangan pupuk kandang puyuh dan pupuk anorganik di lahan sawah Palur, Sukoharjo, Jawa Tengah. Bonorowo Wetlands 2 (1), 11 - 18.

Suratiyah, K. 2006. Ilmu Usahatani. Penebar Swadaya. Jakarta.

Suwatril H.M.R dan Sukristiyonubowo. 2009. Pengaruh pemberian pupuk organik cair MM-17 terhadap sifat kimia tanah, pertumbuhan, dan hasil padi (Oryza Sativa L.) varietas Ciherang. Dalam Anda, M (eds). Prosiding Seminar Nasional dan Dialog Sumberdaya Lahan Pertanian. Balittanah. Bogor, 18 - 20 November 2008.

Wahyudi, I. 2009. Serapan N tanaman jagung (Zea Mays L.) akibat pemberian pupuk guano dan pupuk hijau lamtoro pada Ultisol Wanga. Jurnal Agroland 16 (40): 265-27. 